\title{
Effect of Cooking Methods on Nutritional and Quality Characteris- tics of Fish
}

\author{
Salman Ali ${ }^{*}$, Ayaz Ali' ${ }^{2}$ Riaz Ali Rind ${ }^{2}$, Majid Ali ${ }^{3}$, Zulfiqar Ali Mastoi ${ }^{2}$, Shagufta $\mathrm{Naz}^{3}$, Muhammad \\ Shakir ${ }^{3}$, Rashid Ahmed Qaim Khani ${ }^{1}$
}

${ }^{1}$ Sindh Agriculture University, Tando Jam, Pakistan; ${ }^{2}$ Agriculture Research Institute, Balochistan, Pakistan; ${ }^{3}$ Agriculture Officers Agriculture Extension, Balochistan, Pakistan.

Abstract | The study was carried out during the 2019-20 at laboratory of Institute of Food Sciences and Technology, Sindh Agriculture University, Tandojam. The treatments included in the study were Grilled fish $\mathrm{T}_{1}=$, Fried fish $\mathrm{T}_{2}=$, Microwave $\mathrm{T}_{3}=$ respectively, and treatment were arranged in CRD with the repeats. The results revealed that the cooking in methods were significantly varied (LSD $<0.05)$ for different parameters. The fish cooked in microwave resulted average value of moisture $65.03 \%$, titratable acidity $1.78 \%$, $\mathrm{pH}$ value 6.26 , protein $24.07 \%$, fat $3.76 \%$. Whereas, the fried fish resulted moisture $62.16 \%$, titratable acidity $1.39 \%$, $\mathrm{pH}$ value 5.96 , protein $21.11 \%$, fat $5.93 \%$. The fish grilled resulted in moisture $60.19 \%$, titratable acidity $1.32 \%$, $\mathrm{pH}$ value 5.89 , protein $20.28 \%$, and fat $4.13 \%$. According to the sensory evaluation the result of microwave method were found significantly high than other methods with score of all sensorial parameters i.e. color (7.33), flavor (7.66), texture (8.00), taste (7.66), aroma (7.33) and overall acceptability (8.00). Whereas, the lowest sensory score was recorded in fish with grilled method of cooking and scored (6.00), (5.66), (5.66), (5.33), (5.00), (6.33) in color, flavor, texture, taste, aroma and overall acceptability, respectively.

Received | November 04, 2020; Accepted | January 28, 2021; Published | April 27, 2021

*Correspondence | Salman Ali, Sindh Agriculture University Tando Jam, Pakistan; Email: ghulamnabigola@gmail.com

Citation | Ali, S., A. Ali, R.A. Rind, M. Ali, Z.A. Mastoi, S. Naz, M. Shakir, R.A.Q. Khani. 2021. Effect of cooking methods on nutritional and quality characteristics of fish. Pakistan Journal of Agricultural Research, 34(2): 325-328.

DOI | https://dx.doi.org/10.17582/journal.pjar/2021/34.2.325.328

Keywords | Cooking, Method, Nutritional, Charaterstics, Fish

\section{Introduction}

$\mathrm{F}$ ish is one of the majoranimal protein foods available in the tropics. This has made fishery an important aspect of study. According to (Aberoumand, 2014; E1Lahamy et al., 2019) fish constitutes $40 \%$ of animal protein intake. fish is one of the most perishable and in the tropical climate of most developing countries it wascome unfit for human consumption within about one day of capture, unless it is subjected to some form of processing (Gladyshev et al., 1999).

The principal of fish components are water, protein, lipids and carbohydrates (Ames, 1991), while the followings minerals are commonly found in fish sodium, potassium, calcium, magnesium, phosphorus, sulphur, iron, chlorine, silicon, manganese, zinc, copper, arsenic and iodine (Latimer, 2019). the environment and season (Silva and Chamul, 2000; Głuchowski et al., 2019). Processors have direct intrest in the proximate composition of fish in order to know the nature of the raw material before chilling, freezing, smoking or canning can be correctly applied.

Fish is one of the most complete foods, nutrient quality and quantity an average $100 \mathrm{~g}$ portion provides more than $50 \%$ of the recommended daily protein intake, between $10 \%$ and $20 \%$ of minerals, vitamins 
A, D, and E (Perea et al., 2008; Bastías et al., 2017).

\section{Materials and Methods}

Experimental design $=$ Completely Randomized

Design (CRD)

Treatments $=03\left(\mathrm{~T}_{1}=\right.$ Grilled fish, $\mathrm{T}_{2}=$ fried fish, $\mathrm{T}_{3}$ = microwave)

Replication $=03$

\section{Results and Discussion}

the study was carried out during of 2018-19 at laboratory of Institute of Food Sciences and Technology, Sindh Agriculture University, Tandojam. Treatments included: $\mathrm{T}_{1}=$ Grilled fish, $\mathrm{T}_{2}=$ fried fish, $\mathrm{T}_{3}=$ microwave. Some parameters of economic importance were studied which included: Moisture (\%), Titratable acidity (\%), $\mathrm{pH}$ value, protein (\%), fat (\%), color, flavor, texture, taste, aroma and overall acceptability. The data on the above parameters are presented in Tables 1-11.

Table 1: Moisture (\%) of fish under different cooking methods.

$\begin{array}{lllll}\text { Treatments } & \text { RI } & \text { RII } & \text { RIII } & \text { Mean } \\ \mathrm{T}_{1}=\text { Grilled fish } & 60.12 & 60.25 & 60.20 & 60.19 \mathrm{C} \\ \mathrm{T}_{2}=\text { Fried fish } & 62.80 & 62.75 & 62.90 & 62.81 \mathrm{~B} \\ \mathrm{~T}_{3}=\text { Microwave } & 64.80 & 65.20 & 65.10 & 65.03 \mathrm{~A} \\ \text { S.E. } \pm & 0.0964 & & & \\ \text { LSD 0.05 } & 0.2676 & & & \end{array}$

Table 2: Titratable acidity (\%) of fish under different cooking methods.

$\begin{array}{lllll}\text { Treatments } & \text { RI } & \text { RII } & \text { RIII } & \text { Mean } \\ \mathrm{T}_{1}=\text { Grilled fish } & 1.30 & 1.35 & 1.33 & 1.32 \mathrm{C} \\ \mathrm{T}_{2}=\text { Fried fish } & 1.36 & 1.39 & 1.42 & 1.39 \mathrm{~B} \\ \mathrm{~T}_{3}=\text { Microwave } & 1.75 & 1.82 & 1.79 & 1.78 \mathrm{~A} \\ \text { S.E. } \pm & 0.0136 & & & \\ \text { LSD } 0.05 & 0.0378 & & & \end{array}$

Table 3: pH value of fish under different cooking methods.

$\begin{array}{lllll}\text { Treatments } & \text { RI } & \text { RII } & \text { RIII } & \text { Mean } \\ \mathrm{T}_{1}=\text { Grilled fish } & 5.91 & 5.87 & 5.89 & 5.89 \mathrm{C} \\ \mathrm{T}_{2}=\text { Fried fish } & 5.94 & 5.96 & 5.98 & 5.96 \mathrm{~B} \\ \mathrm{~T}_{3}=\text { Microwave } & 6.28 & 6.24 & 6.26 & 6.26 \mathrm{~A} \\ \text { S.E. } \pm & 0.0163 & & & \\ \text { LSD } 0.05 & 0.0453 & & & \end{array}$

Table 4: Protein (\%) of fish under different cooking methods.

$\begin{array}{lllll}\text { Treatments } & \text { RI } & \text { RII } & \text { RIII } & \text { Mean } \\ \mathrm{T}_{1}=\text { Grilled fish } & 20.20 & 20.35 & 20.30 & 20.28 \mathrm{C} \\ \mathrm{T}_{2}=\text { Fried fish } & 24.05 & 24.08 & 24.10 & 21.11 \mathrm{~B} \\ \mathrm{~T}_{3}=\text { Microwave } & 21.08 & 21.10 & 21.15 & 24.07 \mathrm{~A} \\ \text { S.E. } \pm & 0.0307 & & & \\ \text { LSD 0.05 } & 0.0853 & & & \end{array}$

Table 5: Fat (\%) of fish under different cooking methods.

$\begin{array}{lllll}\text { Treatments } & \text { RI } & \text { RII } & \text { RIII } & \text { Mean } \\ \mathrm{T}_{1}=\text { Grilled fish } & 4.05 & 4.15 & 4.20 & 4.13 \mathrm{~B} \\ \mathrm{~T}_{2}=\text { Fried fish } & 5.80 & 5.90 & 6.10 & 5.93 \mathrm{~A} \\ \mathrm{~T}_{3}=\text { Microwave } & 3.66 & 3.76 & 3.87 & 3.76 \mathrm{C} \\ \text { S.E. } \pm & 0.0356 & & & \\ \text { LSD 0.05 } & 0.0988 & & & \end{array}$

Table 6: Color of fish under different cooking methods.

$\begin{array}{lllll}\text { Treatments } & \text { RI } & \text { RII } & \text { RIII } & \text { Mean } \\ \mathrm{T}_{1}=\text { Grilled fish } & 6.00 & 6.00 & 6.00 & 6.00 \mathrm{C} \\ \mathrm{T}_{2}=\text { Fried fish } & 6.00 & 7.00 & 7.00 & 6.66 \mathrm{~B} \\ \mathrm{~T}_{3}=\text { Microwave } & 8.00 & 7.00 & 7.00 & 7.33 \mathrm{~A} \\ \text { S.E. } \pm & 0.0707 & & & \\ \text { LSD } 0.05 & 0.1730 & & & \end{array}$

Table 7: Flavor of fish under different cooking methods.

$\begin{array}{lllll}\text { Treatments } & \text { RI } & \text { RII } & \text { RIII } & \text { Mean } \\ \mathrm{T}_{1}=\text { Grilled fish } & 6.00 & 6.00 & 5.00 & 5.66 \mathrm{C} \\ \mathrm{T}_{2}=\text { Fried fish } & 7.00 & 6.00 & 5.00 & 6.00 \mathrm{~B} \\ \mathrm{~T}_{3}=\text { Microwave } & 8.00 & 8.00 & 7.00 & 7.66 \mathrm{~A} \\ \text { S.E. } \pm & 0.0408 & & & \\ \text { LSD 0.05 } & 0.0999 & & & \end{array}$

Table 8: Texture of fish under different cooking methods.

$\begin{array}{lllll}\text { Treatments } & \text { RI } & \text { RII } & \text { RIII } & \text { Mean } \\ \mathrm{T}_{1}=\text { Grilled fish } & 5.00 & 6.00 & 6.00 & 5.66 \mathrm{C} \\ \mathrm{T}_{2}=\text { Fried fish } & 6.00 & 6.00 & 7.00 & 6.33 \mathrm{~B} \\ \mathrm{~T}_{3}=\text { Microwave } & 8.00 & 8.00 & 8.00 & 8.00 \mathrm{~A} \\ \text { S.E. } \pm & 0.0408 & & & \\ \text { LSD 0.05 } & 0.0999 & & & \end{array}$

Table 9: Taste of fish under different cooking methods.

$\begin{array}{lllll}\text { Treatments } & \text { RI } & \text { RII } & \text { RIII } & \text { Mean } \\ \mathrm{T}_{1}=\text { Grilled fish } & 5.00 & 5.00 & 6.00 & 5.33 \mathrm{C} \\ \mathrm{T}_{2}=\text { Fried fish } & 6.00 & 7.00 & 7.00 & 6.66 \mathrm{~B} \\ \mathrm{~T}_{3}=\text { Microwave } & 8.00 & 8.00 & 7.00 & 7.66 \mathrm{~A} \\ \text { S.E. } \pm & 0.0408 & & & \\ \text { LSD } 0.05 & 0.0999 & & & \end{array}$


Table 10: Aroma of fish under different cooking methods.

$\begin{array}{lllll}\text { Treatments } & \text { RI } & \text { RII } & \text { RIII } & \text { Mean } \\ \mathrm{T}_{1}=\text { Grilled fish } & 5.00 & 5.00 & 6.00 & 5.00 \mathrm{C} \\ \mathrm{T}_{2}=\text { Fried fish } & 6.00 & 6.00 & 7.00 & 6.33 \mathrm{~B} \\ \mathrm{~T}_{3}=\text { Microwave } & 8.00 & 7.00 & 7.00 & 7.33 \mathrm{~A} \\ \text { S.E. } \pm & 0.0491 & & & \\ \text { LSD 0.05 } & 0.1201 & & & \end{array}$

Table 11: Overall acceptability of fish under different cooking methods.

$\begin{array}{lllll}\text { Treatments } & \text { RI } & \text { RII } & \text { RIII } & \text { Mean } \\ \mathrm{T}_{1}=\text { Grilled fish } & 6.00 & 6.00 & 7.00 & 6.33 \mathrm{C} \\ \mathrm{T}_{2}=\text { Fried fish } & 7.00 & 7.00 & 6.00 & 6.66 \mathrm{~B} \\ \mathrm{~T}_{3}=\text { Microwave } & 8.00 & 8.00 & 8.00 & 8.00 \mathrm{~A} \\ \text { S.E. } \pm & 0.0816 & & & \\ \text { LSD 0.05 } & 0.1998 & & & \end{array}$

\section{Moisture (\%)}

Moisture is the major constituent of the fish. It is evident from the results that the maximum fish moisture $65.03 \%$ was found in the fish cooked under microwave, followed by fried fish with $62.81 \%$ moisture. However, the minimum moisture (60.19\%) was observed with grilled fish. It was recorded that microwave cooked fish has high moisture (65.03\%) content other then fried and grilled fish. The LSD test demonstrated that the differences in moisture (\%) different cooked methods were found significant $(\mathrm{P}<0.05)$.

\section{Titratable acidity (\%)}

maximum fish titratable acidity (1.78\%) under microwave, fried 1.39\%, (1.32\%) grilled fish. The result was found in microwave fish of titratable acidity $(1.78 \%)$ is higher then fried and grilled fish. The LSD test demonstrated that the differences in titratable acidity (\%) different cooked methods were significant $(\mathrm{P}<0.05)$.

\section{pH value}

maximum fish $\mathrm{pH}$ value (6.26) under microwave, fried fish with (5.96) $\mathrm{pH}$ value. However, the minimum $\mathrm{pH}$ value (5.89) grilled fish. In this treatment of cooking methods microwave fish $\mathrm{pH}$ value (6.26) was observed. The LSD test demonstrated that the differences in $\mathrm{pH}$ value different cooked methods were significant $(\mathrm{P}<0.05)$.
Protein (\%)

The protein (\%) under following tables Grilled fish, fried fish and microwave and the results are reported in Table 4 and their ANOVA protein was significantly $(\mathrm{P}<0.05)$ influenced by cooked methods.

\section{Fat (\%)}

Maximum fish fat (5.93\%) under fried, grilled fish with $4.13 \%$ fat. However, the minimum fat (3.76\%) was observed with microwave fish. In this research of different cooking methods for fat determination the high fat (5.93\%) was noted in fried fish then grilled and microwave fish. The LSD test demonstrated that the differences in fat (\%) different cooked methods were significant $(\mathrm{P}<0.05)$.

\section{Color}

maximum fish color (8.25) under microwave, fried fish with 7.40 color. However, the minimum color (6.60) grilled fish. The LSD test demonstrated that the differences in color different cooked methods were significant $(\mathrm{P}<0.05)$.

\section{Flavor}

maximum fish flavor (8.45) when the fish cooked under microwave, followed by fried fish with 7.25 flavor. However, the minimum flavor (6.50) grilled fish. It was found in microwave was better method for fish cooked flavor. The LSD test demonstrated that the differences in flavor different cooked methods were non-significant $(\mathrm{P}>0.05)$.

\section{Texture}

It is evident maximum fish texture (8.35) when the fish cooked under microwave, followed by fried fish with 7.45 texture. However, the minimum texture (6.45) was observed with grilled fish. It was found that microwave was optimum for fish cooked so far the texture. The LSD test demonstrated that the differences in texture different cooked methods were non-significant $(\mathrm{P}>0.05)$.

\section{Taste}

It is evident maximum fish taste (8.40) when the fish cooked under microwave, followed by fried fish with 7.30 taste. However, the minimum taste (6.55) was observed with grilled fish. It was observed that microwave was cooking method on fish is better taste. The LSD test demonstrated that the differences in taste different cooked methods were non-significant $(\mathrm{P}>0.05)$. 
Aroma

It is evident maximum fish aroma (8.25) when the fish cooked under microwave, followed by fried fish with 7.31 aroma. However, the minimum aroma (6.55) was observed with grilled fish. It was found in that microwave fish cooked was good aroma. The LSD test demonstrated that the differences in aroma different cooked methods were non-significant $(\mathrm{P}>0.05)$.

\section{Conclusions and Recommendations}

Microwave cooking method in comparison of fried and grilled cooking methods. While comparing the fried and grilled cooked fish, the results indicated that microwave cooked fish had considerable affect on the proximate composition and microwave cooking were found to be the best cooking methods for healthy eating. While grilled sample was healthier than those fried sample baked fish can be recommended for healthy eating because of harder texture and lower sensorial acceptability of grilled samples. Microwave cooked fish is one of the most effective methods of preparing fish to minimize nutrient losses.

\section{Novelty Statement}

This is baseline study and information about method, nutritional, quality and characteristics of fish.

\section{Author's Contribution}

Salman Ali, Riaz Ali Rind and Majid Ali: Conceived the idea, data collection, data entry in SPSS and analysis.

Ayaz Ali and Shagufta Naz: Wrote the manuscript. Zulfiqar Ali Mastoi: Did SPSS analysis and concluded the study.

Muhammad Shakir and Rashid Ahmed Qaim

Khani: Provided technical input at every step and did overall management.

\section{Conflict of interest}

The authors have declared no conflict of interest.

\section{Reffernces}

Aberoumand, A., 2014. Preliminary studies on nutritive and organoleptic properties in processed fish fillets obtained from Iran. J. Food Sci. Technol., 55(2): 368-376. https://doi. org/10.1590/fst.2014.0042

Ames, G., I. Clucas and S.S. Paul. 1991. Postharvest losses of fish in the tropics. Natural Resources Institute (Great Britain), Overseas Development Administration.

Bastías, J.M., P. Balladares, S. Acuña, R. Quevedo and O. Muñoz. 2017. Determining the effect of different cooking methods on the nutritional composition of salmon (Salmo salar) and chilean jack mackerel (Trachurus murphyi) fillets. PLoS One, 12(7): 0180993. https://doi.org/10.1371/ journal.pone.0180993

El-Lahamy, A.A., K.I. Khalil, S.A. El-Sherif, H.R. Ibrahim and A.A. Mahmud. 2019. Changes in fish during cooking methods (frying and grilling): A review. J. Pub. Heath Catalog, 2(2): 1-4.

Gladyshev, M.I., N.N. Sushchik, G.A. Gubanenko, S.M. Demirchieva and G.S. Kalachova. 1999. Effect of boiling and frying on the content of essential polyunsatured fatty acids in muscle tissue of four fish species. Food Chem. 2007;101: 1694-1700.

Głuchowski, A., E. Czarniecka-Skubina, G. Wasiak-Zys and A.D. Nowak, 2019. Effect of various cooking methods on technological and sensory quality of atlantic salmon. Foods, 8(8):323. https://doi.org/10.3390/ foods 8080323

Latimer, G.W. 2019. Association of Official Analytical Chemists. AOAC International, Gaithersburg, Maryland. https://www. aoac.org/official-methods-of-analysis-21stedition-2019/

Perea, A., E. Gómez, Y. Mayorga and C. Triana. 2008. Caracterización nutricional de pescados de producción y consumo regional en Bucaramanga, Colombia. Arch. Latinoam. Nutri., 58(1): 91-97.

Silva, J.J. and R.S. Chamul. 2000. Composition of marine and freshwater finfish and shellfish species and their products. In: Marine and freshwater products handbook. Technomic Publishing Company, Inc., pp. 31-46. 